\title{
Evaluation of the altimetry from SRTM-3 and planimetry from high-resolution PALSAR FBD data for semi-detailed topographic mapping in the Amazon Region
}

\author{
THIAGO G. RODRIGUES, WALDIR R. PARADELLA and CLEBER G. OLIVEIRA \\ Instituto Nacional de Pesquisas Espaciais/INPE, Divisão de Sensoriamento Remoto/DSR, \\ 12227-010 São José dos Campos, SP, Brasil \\ Manuscript received on March 4, 2010; accepted for publication on January 31, 2011
}

\begin{abstract}
The Brazilian Amazon has a deficit of $35 \%$ of coverage regarding topographic mapping at semi-detailed $(1: 100,000)$ scale. This paper presents an alternative to overcome this scenario using a combination of planialtimetric information from two orbital SAR (Synthetic Aperture Radar) missions. The altimetry was acquired from Shuttle Radar Topography Mission (SRTM), while the planimetry was provided from Fine Beam Dual (FBD) images of the Phased Array L-band Synthetic Aperture Radar (PALSAR) sensor. The research was carried out in the mountainous area of the Serra dos Carajás (Pará State), located on the Amazon region. The quality of the orbital topographic information was evaluated regarding precise planialtimetric measurements acquired from Global Positioning System (GPS) field campaigns. The evaluations were performed following two approaches: (1) the use of Root Mean Square Error (RMSE) and (2) tendency and precision hypothesis tests. The investigation has shown that the planialtimetric quality of the orbital products fulfilled the Brazilian Map Accuracy Standards requirements for 1:100,000 A Class map. Thus, the use of combination of information provided by PALSAR and SRTM-3 data can be considered a promising alternative for production and update of semi-detailed topographic mapping in similar environments of the Amazon region, where topographic information is lacking or presents low quality.
\end{abstract}

Key words: topographic mapping, SRTM-3, ALOS/PALSAR, ortho-images, Amazon Region.

\section{INTRODUCTION}

Due to the adverse environmental condition (rain, cloud and dense vegetation), difficult access and large size (almost 5,500,000 $\mathrm{km}^{2}$ of the national territory), the topographic knowledge of the Brazilian Amazon is still poor in some scales. Almost $35 \%$ of the region lack semi-detailed information (in the mapping community it refers to a scale in the interval from 1:50,000 up to $1: 100,000)$, corresponding to 616 topographic sheets in the 1:100,000 scale (SBC 2006). In addition, the available information for the remainder of the region was mainly produced in the time-frame of 1960 and 1980, and needs to be up-dated or re-mapped.

Correspondence to: Thiago Gonçalves Rodrigues

E-mail: tgrcart@gmail.com
The usage of airphoto based on photogrammetric techniques, for topographic mapping in these areas, is expensive or even not possible due to adverse atmospheric conditions. Digital Surface Model (DSM) represents the elevation of the top surface of vegetation cover and other features (buildings, manmade structures, etc.) above the bare earth (Maune 2007). DSM is also a primary input for topographic mapping. With the launch of the Canadian RADARSAT-1 in 1995, altimetric information extracted from DSM could be for the first time systematically generated using orbital SAR (Synthetic Aperture Radar) radargrammetry or stereoscopy (Toutin 1999). On the other hand, with the ASTER sensor, launched in 1999 on board of Terra platform, it was also possible to generate spaceborne 
THIAGO G. RODRIGUES, WALDIR R. PARADELLA and CLEBER G. OLIVEIRA

optical stereoscopic DSMs from the nadir and backwards positions of the VNIR band 3 (Hirano et al. 2003).

The classification of topographic maps in Brazil should be performed in accordance with the National Cartographic Accuracy Standard (PEC in Portuguese) (Brasil 1984), established by the Brazilian Cartographic Commission. PEC is a statistical indicator $(90 \%$ of probability) for planialtimetric accuracy, corresponding to 1.6449 times the of Root Mean Square Error (RMSE) $(\mathrm{PEC}=1.6449 \times \mathrm{RMSE})$. For a 1:100,000 scale A Class map, the altimetric and planimetric PEC limits are $25 \mathrm{~m}$ $(\mathrm{RMSE}=16.66 \mathrm{~m})$ and $50 \mathrm{~m}(\mathrm{RMSE}=30 \mathrm{~m})$, respectively. Results have been published with RADARSAT1 stereo pairs in distinct environments of the Brazilian Amazon with a general consensus: around $15 \mathrm{~m}$ for flat terrain and $20 \mathrm{~m}$ for mountainous relief (Paradella et al. 2005a, b, Oliveira and Paradella 2008). These results partly fulfilled the national Map Accuracy Standards elevation requirements for 1:100,000 A Class. On the other hand, the altimetry produced from Advanced Spaceborne Thermal Emission and Reflection Radiometer (ASTER) stereo-pairs was better and indicated a RMSE around $10 \mathrm{~m}$ in elevation for mountainous terrains (Oliveira and Paradella 2008). However, adverse atmospheric conditions in the Amazon region preclude the generalized use of ASTER images for systematic basis coverage.

With the Shuttle Radar Topography Mission (SRTM) mission in February 2000, interferometric DSMs were available as free access data for the globe (Farr et al. 2007). The first evaluation of the altimetric quality from SRTM-3 (3 arc-seconds by 3 arc-seconds), in flat and mountainous relief of the Brazilian Amazon, has indicated a RMSE of $12 \mathrm{~m}$ in elevation that fulfilled the topographic mapping requirements for $1: 100,000$ A Class map. These findings justified the choice of SRTM-3 data as a primary elevation source for semidetailed topographic mapping in the region (Oliveira and Paradella 2008). However, it is important to mention that, for cartographic production, updated planimetric information is also necessary.

The advent of the Japanese Advanced Land Observing Satellite (ALOS) satellite in January 2006, with a L-band SAR sensor (PALSAR), opened new pers- pectives to a wide range of applications in the Geosciences (Silva et al. 2009, Paradella et al. 2009). PALSAR images with new attributes of high-resolution, variable incidence, multi-polarization and polarimetric capabilities have been extensively collected for test-sites located in the Carajás Mineral Province.

This paper is an outgrowth of previous investigations on the use of imaging radar technology to overcome the critical lack of cartographic information in tropical environments of Brazil. In this study, we expanded the previous research with SRTM-3 DSM by examining the altimetric accuracy and the quality of derived contour lines of this interferometric product. In addition, we also evaluated the planimetric quality of PALSAR Fine Beam Dual (FBD) ortho-images. Thus, it was possible to evaluate the planialtimetric quality of both SAR products, which are fundamental inputs for semi-detailed topographic mapping in the Amazon region.

\section{STUDY SITE}

The test-area is located within the Carajás Mineral Province (Pará State), the most important Brazilian mineral province that has the world's largest iron deposits and important deposits of Mn (Azul), Cu (Salobo, Sossego) and $\mathrm{Ni}$ (Vermelho), among others. It includes part of Água Azul do Norte, Canaã dos Carajás, Curionópolis, Marabá and Parauapebas municipalities. The selected area comprises around $3,059.47 \mathrm{~km}^{2}$ corresponding to the Serra dos Carajás (IBGE sheet SB-22Z-A-II) 1:100,000 scale topographic sheet, which was produced from airphotos by the Brazilian Institute of Geography and Statistics (IBGE in Portuguese) during the 1967-1981 period (Fig. 1).

The region is characterized by a set of hills and plateaus (altitudes from 500 to $900 \mathrm{~m}$ ) surrounded by southern and northern lowlands (altitudes around $200 \mathrm{~m}$ ) totally covered by Ombrophilous Equatorial forest (Paradella et al. 1994). Chemical weathering, thick oxisols ("latosols"), few outcrops and thick tropical rainforest are some of the main characteristics of the region. Due to the economic importance of this area, there is an increasing need to provide accurate maps to support exploration and also environmental programs. A reasonable amount of optical and radar data has been 


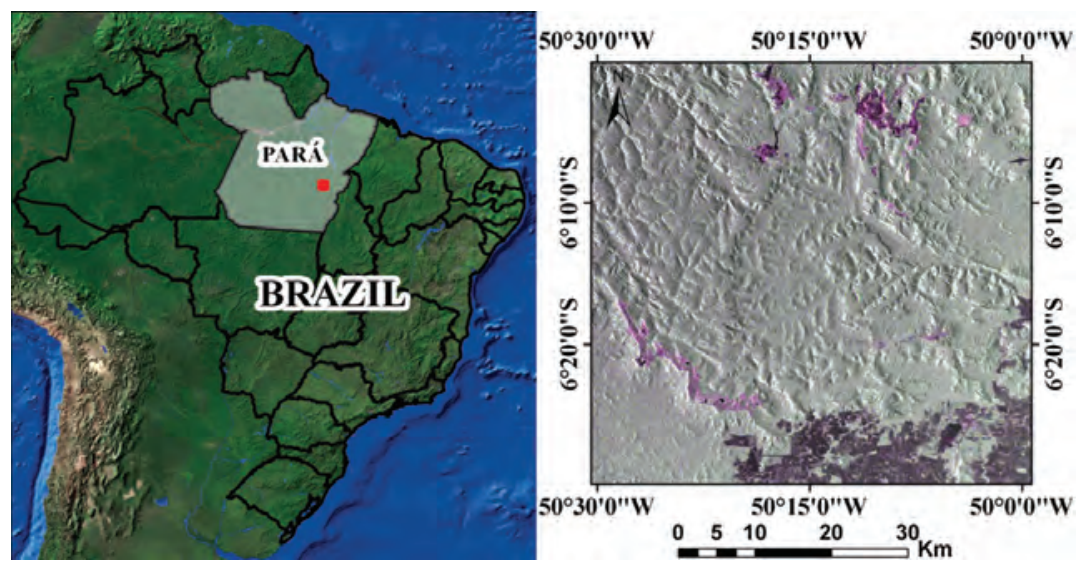

Fig. 1 - Location of the study area.

acquired and evaluated in the Province for geological (Paradella et al. 1994, 1997, Santos et al. 2003, Veneziani et al. 2004, Lobato et al. 2005, Silva et al. 2005, Teruiya et al. 2008, Silva et al. 2009) and topographic mapping (Paradella et al. 2005a, b, Oliveira and Paradella 2008, 2009, Oliveira et al. 2010).

\section{DATASET}

\section{ALOS/PALSAR}

The ALOS satellite, an enhanced successor of the Japanese Earth Resources Satellite 1 (JERS-1), was launched from JAXA (Japan Aerospace Exploration Agency) Tanegashima Space Center in January 2006. ALOS operates from a sun-synchronous orbit at $691 \mathrm{~km}$, with a 46-day recurrence cycle carrying a payload of three remote sensing instruments: the Panchromatic Remote Sensing Instrument for Stereo Mapping (PRISM), the Advanced Visible and Near-Infrared Radiometer type 2 (AVNIR-2), and the polarimetric Phased Array L-band Synthetic Aperture Radar (PALSAR). The PALSAR sensor has the capacity to operate with a wide range of off-nadir angles and resolutions in a single-, dual-, and quad-pol mode (JAXA 2007).

The PALSAR instrument, developed as a joint project by JAXA and the Japan Resources Observation System Organization (JAROS), is a L-band SAR that allows day-and-night and all-weather land observation. The center frequency of the L-band used is 1,270 MHz. PALSAR has five typical modes, i.e., Fine Beam Single (FBS), Fine Beam Dual (FBD), Direct Transmis- sion (DSN), ScanSAR (SCAN), and Polarimetric (PLR). In fine-resolution observation modes (FBS or FBD), the incident angle variation is 8 to $60^{\circ}$, the observation swath is 40 to $70 \mathrm{~km}$, and the range resolution is 7 to $44 \mathrm{~m}$ for chirp-bandwidth $28 \mathrm{MHz}$ and 14 to $88 \mathrm{~m}$ for chirp-bandwidth $14 \mathrm{MHz}$, respectively (Shimada et al. 2007).

Geometric and radiometric calibration results of the PALSAR using in-total 500 calibration points collected worldwide have indicated a geometric accuracy of $9.3 \mathrm{~m}$ for the FBS, FBD, DSN, and POL modes, and around $70 \mathrm{~m}$ for the ScanSAR mode. The radiometric accuracy of the products was around $0.64 \mathrm{~dB}$ (Shimada et al. 2007). Examples of PALSAR applications in Brazil can be seen in Silva et al. (2009), Paradella et al. (2009) and Santos et al. (2009). The PALSAR images available for the investigation were acquired over Carajás in September 2007. A total of four FBD (L-HH, L-HV) scenes were collected under distinct look-azimuth (descending pass, ascending pass), moderate incidence, and a swath width of $75 \mathrm{~km}$ (details in Table I).

\section{SRTM}

The Shuttle Radar Topography Mission (SRTM) was an international project spearheaded by the U.S. National Geospatial-Intelligence Agency (NGA) and the National Aeronautics and Space Administration (NASA), with the participation of Deutschen Zentrum für Luft - und Raumfahrt (DLR) from Germany and Agenzia Spaziale Italiana (ASI) from Italy (Gesch et al. 2006, 
TABLE I

PALSAR data characteristics.

\begin{tabular}{l|c|c|c|c}
\hline Image code & 080153740 & 080153750 & 076437060 & 076437050 \\
\hline Product level & $1.5(16 \mathrm{bits})$ & $1.5(16 \mathrm{bits})$ & $1.5(16 \mathrm{bits})$ & $1.5(16 \mathrm{bits})$ \\
\hline Polarization & $\mathrm{HH}, \mathrm{HV}$ & $\mathrm{HH}, \mathrm{HV}$ & $\mathrm{HH}, \mathrm{HV}$ & $\mathrm{HH}, \mathrm{HV}$ \\
\hline Look azimuth & $282^{\circ}($ desc. $)$ & $282^{\circ}($ desc. $)$ & $78^{\circ}$ (asc.) & $78^{\circ}$ (asc.) \\
\hline Acquisition date & $09 / 27 / 2007$ & $09 / 27 / 2007$ & $09 / 02 / 2007$ & $09 / 02 / 2007$ \\
\hline Inc. Angle & $38.894^{\circ}$ & $38.894^{\circ}$ & $39.019^{\circ}$ & $39.019^{\circ}$ \\
\hline N. of looks $(\mathrm{rg} \times \mathrm{az})$ & $4 \times 1$ & $4 \times 1$ & $4 \times 1$ & $4 \times 1$ \\
\hline Spatial resolution $(\mathrm{rg} \times \mathrm{az})$ & $20 \times 10 \mathrm{~m}$ & $20 \times 10 \mathrm{~m}$ & $20 \times 10 \mathrm{~m}$ & $20 \times 10 \mathrm{~m}$ \\
\hline Pixel spacing & $12.5 \times 12.5 \mathrm{~m}$ & $12.5 \times 12.5 \mathrm{~m}$ & $12.5 \times 12.5 \mathrm{~m}$ & $12.5 \times 12.5 \mathrm{~m}$ \\
\hline
\end{tabular}

Farr et al. 2007). The main mission objective was to obtain elevation radar data on a near-global scale to generate the most complete high-resolution digital topographic database of the planet.

On February 11, 2000, the SRTM payload onboard Space Shuttle Endeavour was launched into space with two radar antennas, one located in the shuttle's payload bay and the other on the end of a $60 \mathrm{~m}$ (200 foot) mast. In order to gather elevation data of Earth's surface, SRTM used the technique of interferometry, with two images taken from different vantage points of the same area. Two kinds of DSMs were produced: (1) a C-band DSM, originally with 1 arc-second original data ( $30 \mathrm{~m}$ of spatial resolution), and further with a downgraded resolution of 3 arc-seconds, with $90 \mathrm{~m}$ of spatial resolution (SRTM-3), and (2) a X-band DSM also with 1 arc-second resolution data (30 $\mathrm{m}$ spatial resolution). Details can be found in Hoffmann and Walter 2006.

According to Rodriguez et al. (2005), the performance for SRTM DSMs over a grid of 1 arc-second by 1 arc-second for South America showed an absolute geolocation and height errors ( $90 \%$ of probability) of 9 and $6.2 \mathrm{~m}$, respectively. On the other hand, results related to SRTM-3 (3 arc-seconds by 3 arc-seconds) in Ecuador, Honduras and Colombia indicated an average error of $8 \mathrm{~m}$ in elevation (Jarvis et al. 2004). Finally, results from Oliveira and Paradella (2008) indicated elevation errors ( $90 \%$ of probability) of 19 and $21 \mathrm{~m}$, respectively, for flat and mountainous relief in the Brazilian Amazon. The SRTM-3 data used in this research were acquired at $\mathrm{ftp}: / / \mathrm{e} 0 \mathrm{srp} 01 \mathrm{u}$.ecs.nasa.gov/srtm/version2/SRTM3 in Lat/Long coordinates related to the World Geodetic System 1984 (WGS84) ellipsoid and the Earth Gravitational
Model 1996 (EGM96) vertical datum and available in HGT file format.

\section{GPS FIELD MEASUREMENTS}

Precise planialtimetric measurements from Global Positioning System (GPS) were acquired in the test-site and used as Ground Control Points (GCPs) for the ortho-rectification of the PALSAR images and as Independent Check Points (ICPs) for calculation of altimetric (SRTM-3) and planimetric (PALSAR images) accuracies. Two dual frequency Geodetic GPS receptors were used for the static GPS measurements, and a total of 48 static measurements and 35,000 kinematics measurements were collected during field campaigns in September-October 2002 using helicopter and vehicle (Fig. 2). The maximum errors with a probability of $68.3 \%(1 \sigma)$ for the estimated positions were $18 \mathrm{~cm}$ (latitude), $75 \mathrm{~cm}$ (longitude) and $24 \mathrm{~cm}$ (ellipsoidal height) in geodetic coordinates related to the WGS84 ellipsoid (Paradella et al. 2005b).

It is important to mention that the decision about the necessary GPS measurements, to be used as GCPs and ICPs in the whole processing (ortho-rectification and planialtimetric quality assessments), depends on several aspects: site characteristics and access, method of field collection, sensor type and spatial resolution, geometric model, final expected accuracy, etc. Basically, the quality and number of the available GCPs will have direct impact on the error propagation and overall error budget of the bundle adjustment of the geometric correction modeling (Toutin 2004). Theoretically, 8 GCPs are required for each FBD-PALSAR 1.5 image in the process of ortho-image generation using OrthoEngine package 


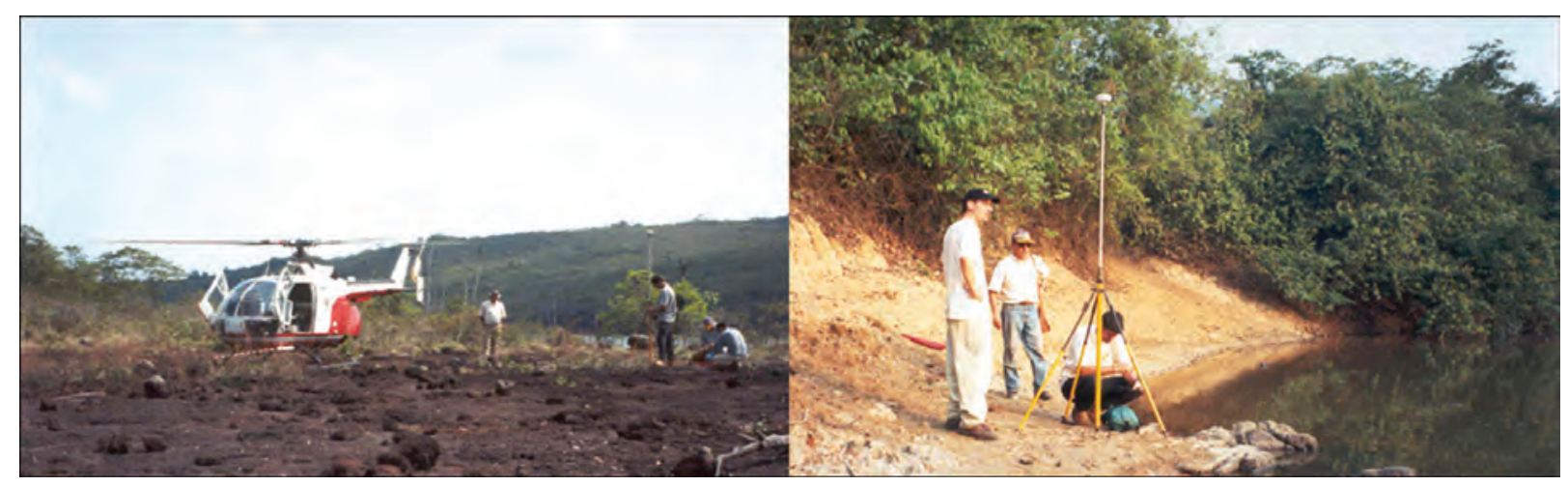

Fig. 2 - Details of the GPS field campaigns in Carajás.

(PCI Geomatics 2010). However, a larger number is generally recommended to improve the accuracy of the product with samples ideally chosen on a variety of locations and ground elevations, particularly at the lowest and highest elevation. On the other hand, ICPs number also plays a key role in quality control for mapping production. This is a controversial issue since a balance has to be reached between few ICPs, giving invalid accuracy estimation and an excessive number, providing a safe analysis with unrealistic cost. Based on the literature, a minimum of 20 up to 28 well-distributed ICPs within a map is normally accepted (Merchant 1982, ASPRS 1989 , USGS 1998).

\section{METHODOLOGY}

\section{Processing OF THE SRTM-3 DSM}

The SRTM-3 DSMs were originally referenced in the WGS84 (horizontal datum) and EGM96 (vertical datum) in HGT files format. Data were imported and merged into a PCI Geomatica file format (PIX) with 90 m pixel spacing, followed by the application of an interpolation function to fill no-data holes using Geomatica Focus from PCI software (PCI Geomatics 2010). In order to make the SRTM-3 DSM and GPS points datums with the reference datum adopted in Brazil (South American Datum 1969-SAD69/Imbituba) compatible, the following steps were necessary: (1) SRTM-3 DSM - calculation of the geoid undulation of the EGM96 model using the INPT software from NGA (NGA 2009); (2) SRTM-3 DSM - conversion of the orthometric altitude (EGM96) to ellipsoidal altitude (WGS84) based on PCI Geomatica software (PCI Geomatics 2010); (3) SRTM-3 DSM and GPS measurements - calculation of the geoid undulation for the orthometric altitude determination (Imbituba) using MAPGEO 2004 software (IBGE 2009); (4) SRTM-3 DSM and GPS measurements - conversion of the ellipsoidal altitude (WGS84) to orthometric altitude (Imbituba) based on PCI Geomatica software (PCI Geomatics 2010); and (5) SRTM-3 DSM and GPS measurements - conversion data from WGS84 to SAD69 using PCI Geomatica. Finally, a contour lines vector segment was produced with a $50 \mathrm{~m}$ interval from the raster SRTM-3 DSM (Universal Transverse Mercator - UTM projection, SAD69 and Imbituba vertical datum). Figure 3 presents the steps used in order to convert SRTM and GPS points, to SAD 69 and to the vertical reference system Imbituba.

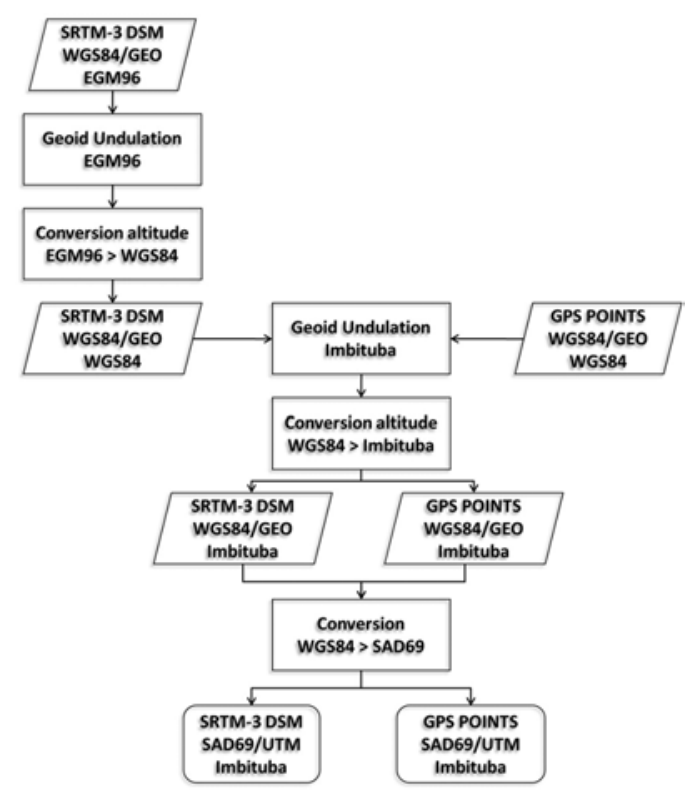

Fig. 3 - Steps used during the processing of SRTM-3 data. 


\section{ORTHO-RECTIFICATION OF THE PALSAR IMAGES}

Since the test-area has a significant topographic relief, the geometric correction should take this into consideration in order to produce an ortho-image product. An ortho-image is a georeferenced image in which the displacement of objects due to sensor orientation and terrain relief has been removed. It has the geometric characteristics of a map and the image qualities of a photograph. In other words, the scale is kept constant on the whole scene. The geometric correction was based on a mathematical and accurate geometric model of orthorectification, which considers the distinct distortions relative to the global geometry of viewing, such as distortions relative to the platform and the sensor, Earth geoidellipsoid including elevation, and cartographic projection (ellipsoid-cartographic plane). The following steps are normally used during an ortho-retification task with the OrthoEngine Software: (a) reading of the image data, (b) GCP collection, (c) model calculations, (d) ortho generation. Details of the ortho-rectification process can be found in Toutin and Carbonneau (1992), and the characteristics of the process with OrthoEngine can be seen in PCI Geomatics (2010). Two mathematical models have been used for satellite sensor orientation and 3D geo-positioning in the last decades: rigorous mathematical model (or physical model) and non-rigorous mathematical model (empirical model). Normally, rigorous mathematical models are more accurate than empirical models because they consider all the sensor information, as well as the satellite and the Earth motion (Shaker 2008). An example of $3 D$ physical model is the threedimensional CCRS physical model that was developed as an integrated and unified geometric model to geometrically process SAR images, and has also benefited from theoretical work in celestial mechanics to better determine the satellite's oscillatory parameters over long orbits (Toutin et al. 1992). This model was subsequently adapted to RADARSAT-1 images by Toutin (1998) in the evaluation of the geometric accuracy of RADARSAT-1 images. This adapted model (Toutin's 3D Radargrammetric) represents the well-known collinearity condition (and coplanarity condition for stereo model), and integrates different distortions relative to the global geometry of view, including effects relative to the plat- form, the sensor, the Earth and the cartographic projection. This model is embodied into PCI Geomatica OrthoEngine software and details are presented in Ostrowski and Cheng (2000).

The PALSAR images were ortho-rectified using Toutin's 3D Radargrammetric with 28 GCPs and the SRTM-3 DSM. The Enhanced Frost Filter $(3 \times 3$ pixels window) was used to filter the speckle noise. More details on the filter can be found in Frost et al. (1982). Finally, two FBD-PALSAR ortho-images mosaics were produced with the geometrically correct images, one with ascending and the other with the descending scenes (Fig. 4).

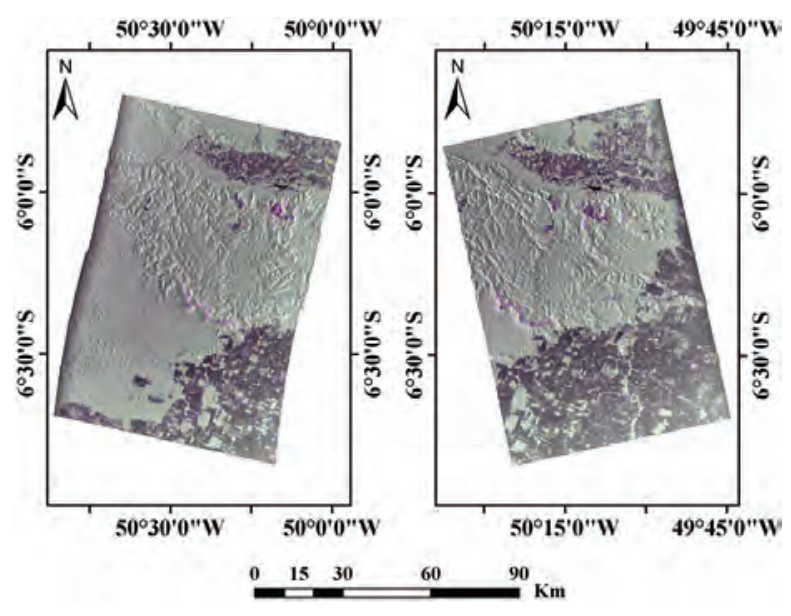

Fig. 4 - Descending (left) and ascending (right) FBD-PALSAR (R-LHH, G-LHV, B-LHH) ortho-images mosaics.

\section{STATISTICAL ANALYSIS}

The altimetric accuracy of the SRTM-3 DSM was estimated by comparison with the DSM elevation values $\left(Z_{i}\right)$ and the real values given by $\operatorname{ICPs}\left(Z_{G P S}\right)$. For the planimetric evaluation of the PALSAR ortho-images mosaics, the comparison was between planimetric coordinates $\left(E_{i}, N_{i}\right)$ of the products and the planimetrics values from ICPs $\left(E_{G P S}, N_{G P S}\right)$. In the case of the planimetric assessment of the SRTM-3 DSM, a comparison was performed taking into account the planimetric positions of the contour lines derived from DSM and the closest planimetric positions of kinematic measurements from GPS field campaign (Fig. 5).

The accuracy analysis was carried out following two approaches: (1) the overall classifications of the SRTM-3 DSM considering the altimetric PEC, and of 


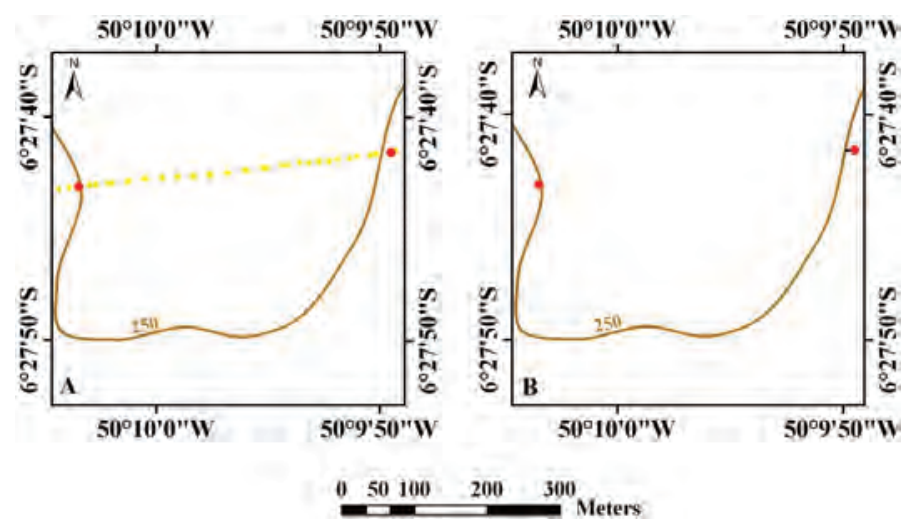

Fig. 5 - (A): kinematics GPS profile measurements (yellow dots) and the SRTM-3 elevation contour line (brown line). (B): selected points (red dots) used for the planimetric assessment.

the DSM and PALSAR ortho-images mosaics regarding the planimetric PEC, and (2) tendency and precision hypothesis tests for both data. The altimetric quality of the SRTM-3 DSM was estimated based on RMSE values given by the Equation 1 (ASPRS 1989, NSDI 1998), and on Vertical Map Accuracy Standard (VMAS) values, which correspond to the vertical error with $90 \%$ of probability (Eq. 2) (NSDI 1998).

$$
\begin{aligned}
R M S E_{A} & =\sqrt{\Sigma\left(Z_{i}-Z_{r e f}^{2} / n\right.} \\
V M A S & =1.6449 \times R M S E
\end{aligned}
$$

where,

$Z_{i}=i$ th elevation extracted from SRTM DSM;

$Z_{\text {ref }}=i$ th elevation extracted from GPS; and

$n=$ number of samples.

For the planimetric classification of the DSM and the PALSAR ortho-images mosaics, planimetric RMSE (Eq. 3, ASPRS 1989, NSDI 1998) and Circular Map Accuracy Standard (CMAS) values, which represent the circular error with $90 \%$ de probabilities (Eq. 4), were also used.

$$
\begin{gathered}
R M S E_{p}=\sqrt{\frac{\Sigma\left(E_{i}-E_{r e f}\right)^{2}+\left(N_{i}-N_{r e f}\right)^{2}}{n}} \\
C M A S=2.146 \times R M S E
\end{gathered}
$$

where,

$E_{i}$ e $N_{i}=i$ th planimetric coordinates extracted from planialtimetric products;
$E_{\text {ref }}$ e $N_{\text {ref }}=i$ th planimetric coordinates extracted from ICPs; and

$n=$ number of samples.

Finally, the tendency and precision hypothesis tests were based on the methodology proposed by Galo and Camargo (1994), which takes into account computed discrepancies and standard deviations. Tendency analysis was used to check the presence of systematic errors. It was based on the hypothesis $\left(\mathrm{H}_{0}: \hat{\mu}=0\right.$; $\mathrm{H}_{1}: \hat{\mu} \neq 0$ ), whose acceptance or rejection is controlled by the computed Student $t$ statistics test (Eq. 5) compared with the theoretical $t_{(n-1, \alpha / 2)}$ value.

$$
t_{x}=\frac{\hat{\mu}}{\hat{\sigma}} \times \sqrt{n}
$$

where,

$\hat{\mu}=$ mean of sample discrepancies;

$\hat{\sigma}=$ standard deviation of sample discrepancies; and $n=$ number of samples.

Precision analysis uses comparison of the variance of sample discrepancies $\left(\hat{\sigma}^{2}\right)$ to their respective values obtained from the Brazilian standards, according to the Cartographic Commission - CONCAR (Brasil 1984). The test is carried out using a hypothesis about the mean and standard deviation of the sample for each of the altimetric value. Chi-squared $\left(\chi^{2}\right)$ is the statistical test that was applied. The accuracy of the product can be estimated in the $Z$ values using standard statistical methodology involving the comparison of a sample value of $\chi^{2}$ and the tabled value $\chi_{(n-1, \alpha)}^{2}$. This analysis 


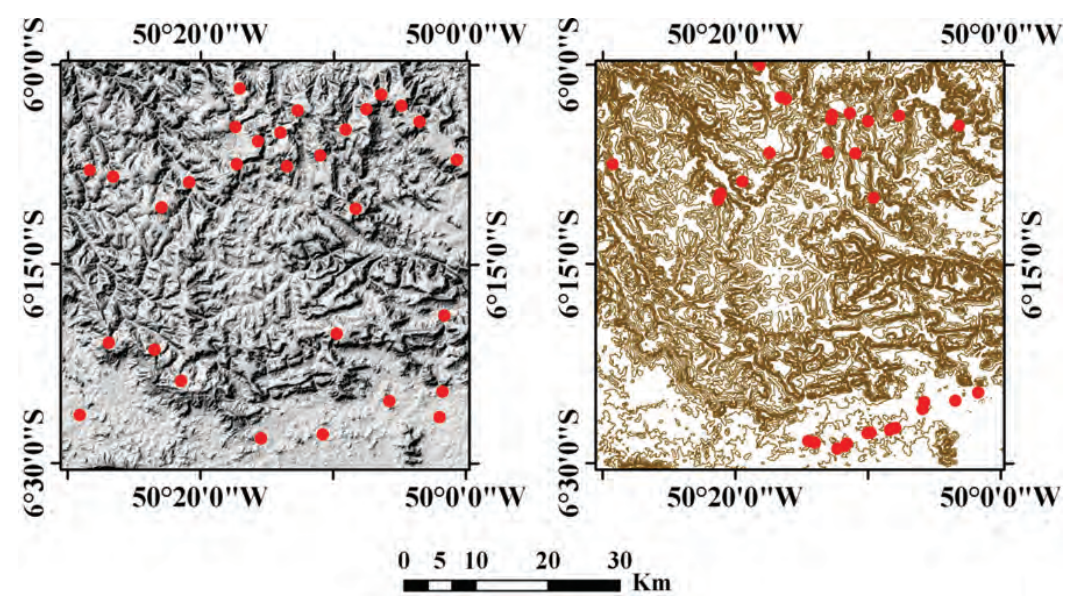

Fig. 6 - Distribution of the ICPs (red dots) for the planialtimetric evaluation of the SRTM-3 DSM (left) and corresponding elevation contour lines (right).

will point out if the product fulfills the accuracy for the requested scale.

$$
\chi_{X}^{2}=(n-1) \times \hat{\sigma}^{2} / \hat{\sigma}_{x}^{2}
$$

where $n$ is the number of samples.

\section{RESULTS AND DISCUSSION}

A total of 30 ICPs was selected for the planialtimetric evaluation of the SRTM-3 DSM (Fig. 6). For the orthorectification process of the ascending and descending PALSAR data, 28 GCPs were used for the modeling and ortho-images generation, and 32 ICPs for the planimetric quality assessment (Fig. 7).

The quantitative results for the SRTM-3 DSM expressed by RMSE, VMAS, tendency and precision analysis are presented in Table II. The analysis of these results allows important findings: (1) using the PEC classification limit (RMSE $\leq 16.66 \mathrm{~m})$ and the results of Chi-square test $\left(\chi_{Z \text { (sample) }}^{2}<39.087\right)$, the SRTM-3 DSM altimetry fulfilled the requirements for a 1:100,000 scale A Class map; (2) however, the statistics of tendency analysis $\left(\left|t_{Z(\text { sample })}\right|<1.699\right)$ indicates the presence of a positive offset in the $Z$ direction. A simple way to eliminate this bias is to add the discrepancy mean value in the $Z$ component. Distinct causes can be considered to explain the observed bias, including: the inherent relative characteristic of the SRTM-3 DSM, since the phase return in C-band was influenced by the attributes (height, structure and density) of the rainforest (Farr et al. 2007); influence of topographic aspect, which was attributed to the effect of incidence angle of the SAR used to produce the interferometric DSM (Jarvis et al. 2004), and also the poor spatial resolution (90 m) that could be significant in steeper slopes.

TABLE II

Values of Mean of Discrepancy $\left(\hat{\mu}_{Z}\right)$, Standard Deviation $\left(\hat{\sigma}_{Z}\right)$, Root Mean Square Error (RMSE), Vertical Map Accuracy Standard (VMAS), Tendency and Precision analysis of SRTM-3 DSM.

\begin{tabular}{lr}
\hline$\hat{\mu}_{Z}(m)$ & 7.977 \\
\hline$\hat{\sigma}_{Z}(m)$ & 5.441 \\
\hline$R M S E_{Z}(m)$ & 9.605 \\
\hline$V M A S_{Z}(m)$ & 15.798 \\
\hline$t_{(n-1 ; 5 \%)}$ & 1.699 \\
\hline$T_{Z(\text { sample })}$ & 8.029 \\
\hline$\chi_{(n-1 ; 10 \%)}^{2}$ & 39.087 \\
\hline$\chi_{Z(\text { sample })}^{2}$ & 3.091 \\
\hline$\left|t_{Z(\text { sample })}\right|<t_{(n-1 ; 5 \%)}$ & False \\
\hline$\chi_{Z(\text { sample })}^{2}<\chi_{(n-1 ; 10 \%)}^{2}$ & True \\
\hline
\end{tabular}

Regarding the planimetric assessment of SRTM3 and FBD-PALSAR ortho-images mosaics, the results of RMSE, CMAS, tendency and precision analysis are presented in Table III.

These results showed that the planimetric accuracy of SRTM-3 DSM and FBD-PALSAR ortho-images mo- 


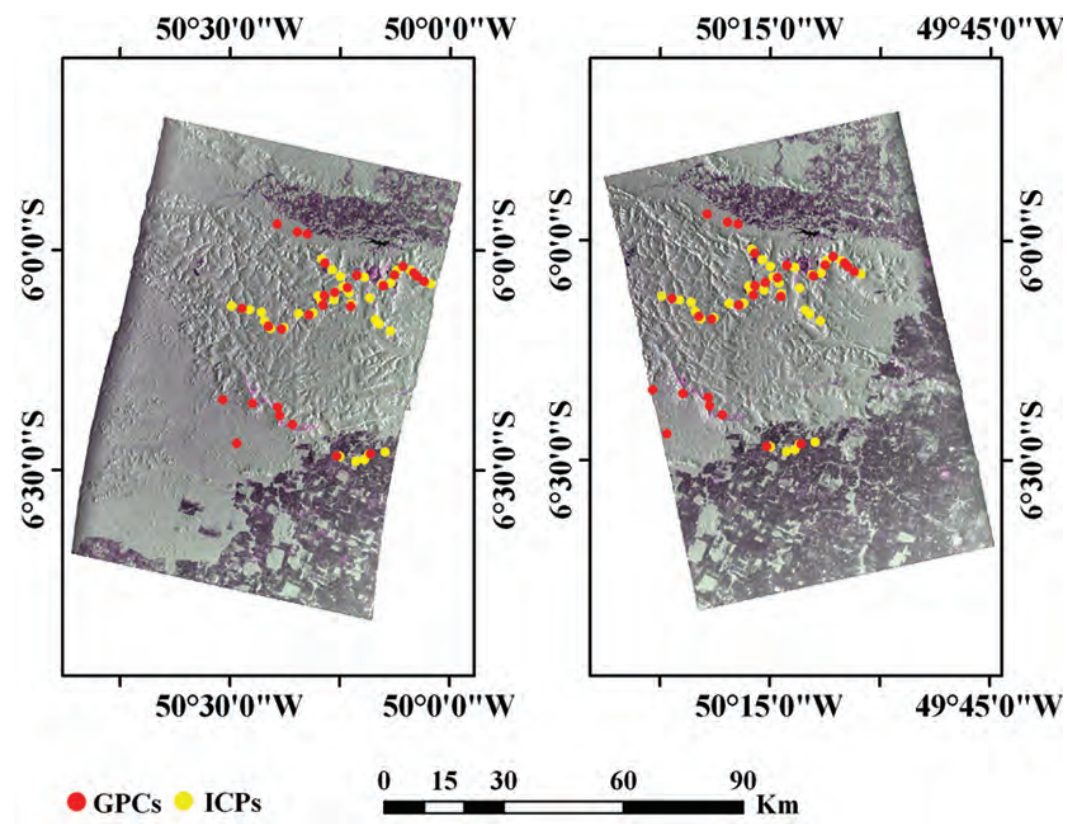

Fig. 7 - Distribution of the GCPs (yellow dots) and ICPs (red dots) for the descending and ascending FBD-PALSAR (R-LHH, G-LHV, B-LHH) ortho-images mosaics.

saics (RMSE $\leq 21.21 \mathrm{~m}$ ) also fulfilled the PEC requirements for 1:100,000 A Class Map. In addition, no bias was detected for the interferometric DSM, while a systematic offset (bias) in planimetry is present for the $\mathrm{N}$ component in the PALSAR ortho-images mosaics. These findings are in accordance with previous results in the literature, which emphasized the quality of both sources of data (SRTM-3 and PALSAR-FBD) for semidetailed topographic mapping purposes (Jarvis et al. 2004, Rodriguez et al. 2005, Cheng 2007, Oliveira and Paradella 2008).

Usually, elevation information is expressed in cartographic maps by contour lines. The results confirmed the altimetric and planimetric qualities of the contour lines produced from SRTM-3 DSM, and highlighted its potential as an input for cartographic map production at semi-detailed scale. On the other hand, due to the ability of FDB PALSAR images to highlight target variations on the terrain, distinct image patterns with arrays of tonal/textural patterns can be meaningfully related to important layers (drainages, roads, land-use, etc.), which are also necessary as thematic information for mapping purposes. Figure 8 shows the topographic map of the study area produced through the combination of infor- mation from SRTM-3 DSM (contour lines) and FBD PALSAR (drainage, land-use and vegetation patterns) that fulfilled planialtimetric PEC limits for 1:100,000 A Class.

\section{CONCLUSIONS}

The study supports the conclusion that, for mountainous terrains in the Brazilian Amazon similar to the research area, the planialtimetric quality of SRTM-3 DSM and FBD-PALSAR data totally fulfilled the Brazilian Map Accuracy Standards (PEC) requirements for 1:100,000 A Class topographic maps. Bias effects were detected for both products, expressed by vertical shift component for the SRTM-3 DSM and horizontal shift in N component for the PALSAR ortho-images mosaics, which can be partially attenuated adding the discrepancy mean value in the vertical and horizontal components. It is important to mention that, due to the effect of the vegetation in the SRTM data, the contour lines generated from the DSM are a closer expression of the topographic relief modeling. Thus, the combination of altimetry derived for SRTM-3 and planimetry from FBD-PALSAR data, shows to be a powerful alternative for semi-detailed topographic mapping programs in large sectors of the 


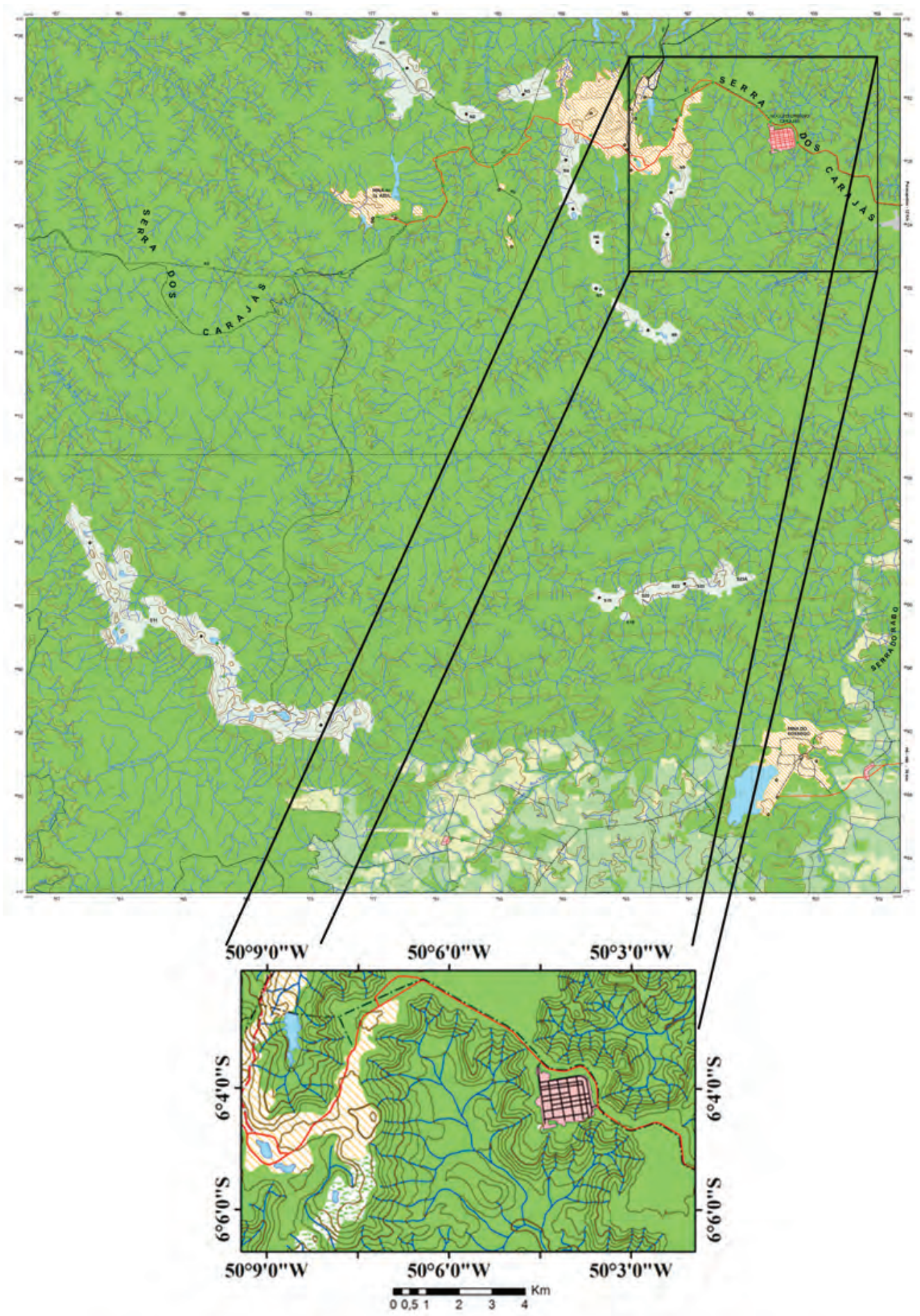

$\square$ URBAN AREA $\square$ FOREST M MINERAL EXTRACTIONAREA $\square$ LAKE

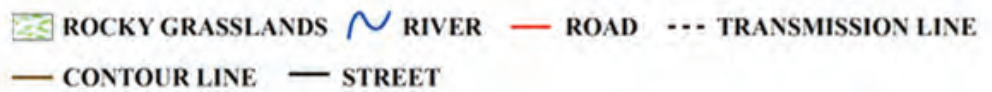

Fig. 8 - Final map (and detail) of the Serra dos Carajás sheet (1:100,000 scale). 
TABLE III

Values of Discrepancy Mean $(\hat{\mu})$, Standard Deviation $(\hat{\sigma})$, Root Mean Square Error (RMSE), Vertical Map Accuracy Standard (VMAS), Tendency and Precision analysis of SRTM-3 and PALSAR planimetry of both kinds of orbit (descending and ascending).

\begin{tabular}{|c|c|c|c|}
\hline & SRTM-3 & $\begin{array}{c}\text { Descending FBD- } \\
\text { PALSAR ortho- } \\
\text { imagesmosaic }\end{array}$ & $\begin{array}{l}\text { Ascending FBD- } \\
\text { PALSAR ortho- } \\
\text { imagesmosaic }\end{array}$ \\
\hline$\hat{\mu}_{E}(m)$ & 2.096 & 1.045 & -0.224 \\
\hline$\hat{\sigma}_{E}(m)$ & 16.197 & 8.715 & 5.620 \\
\hline$R M S E_{E}(m)$ & 16.062 & 8.641 & 5.537 \\
\hline$C M A S_{E}(m)$ & 34.468 & 18.508 & 11.857 \\
\hline$t_{(n-1 ; 5 \%)}$ & 1.699 & 1.695 & 1.695 \\
\hline$t_{E(\text { sample })}$ & 0.709 & 0.678 & -0.2414 \\
\hline$\chi_{(n-1 ; 10 \%)}^{2}$ & 39.087 & 41.422 & 41.422 \\
\hline$\chi_{E(\text { sample })}^{2}$ & 16.906 & 5.233 & 2.176 \\
\hline$\left|t_{E(\text { sample })}\right|<t_{(n-1 ; 5 \%)}$ & True & True & True \\
\hline$\chi_{E(\text { sample })}^{2}<\chi_{(n-1 ; 10 \%)}^{2}$ & True & True & True \\
\hline$\hat{\mu}_{N}(m)$ & -0.575 & 5.762 & 3.035 \\
\hline$\hat{\sigma}_{N}(m)$ & 11.611 & 9.531 & 6.577 \\
\hline$R M S E_{N}(m)$ & 11.431 & 11.010 & 7.150 \\
\hline$C M A S_{N}(m)$ & 24.530 & 23.578 & 15.312 \\
\hline$t_{(n-1 ; 5 \%)}$ & 1.699 & 1.695 & 1.695 \\
\hline$t_{N(\text { sample })}$ & -0.271 & 3.420 & 2.610 \\
\hline$\chi_{(n-1 ; 10 \%)}^{2}$ & 39.087 & 41.422 & 41.422 \\
\hline$\chi_{N(\text { sample })}^{2}$ & 8.689 & 6.258 & 2.980 \\
\hline$\left|t_{N(\text { sample })}\right|<t_{(n-1 ; 5 \%)}$ & True & False & False \\
\hline$\chi_{N(\text { sample })}^{2}<\chi_{(n-1 ; 10 \%)}^{2}$ & True & True & True \\
\hline
\end{tabular}

Brazilian Amazon, where terrain information is seldom available or presents low quality.

\section{ACKNOWLEDGMENTS}

The authors would like to thank JAXA for the PALSAR data (ALOS RA \#219). Coordenação de Aperfeiçoamento de Pessoal de Nível Superior (CAPES) and Conselho Nacional de Desenvolvimento Científico e Tecnológico $(\mathrm{CNPq})$ are also acknowledged for a grant received by the first (Bolsa de Mestrado, Process 133516/ 2008-3) and second authors (Bolsa PQ, Process \#3009$85 / 90-8)$. The authors would like to thank the referees for their critiques and suggestions that helped to improve the quality of the paper.

\section{RESUMO}

A Amazônia brasileira possui um déficit de $35 \%$ de cobertura em relação ao mapeamento topográfico na escala de semidetalhe (1:100.000). Este trabalho apresenta uma alternativa para superar este cenário usando a combinação de informação planialtimétrica de duas missões SAR (Radar de Abertura Sintética) orbitais. A altimetria foi adquirida da Shuttle Radar Topography Mission (SRTM), enquanto que a planimetria foi fornecida de imagens Fine Beam Dual (FBD) do sensor Phased Array L-band Synthetic Aperture Radar (PALSAR). A pesquisa foi desenvolvida na área montanhosa da Serra dos Carajás (Estado do Pará) localizada na região Amazônica. A qualidade das informações topográficas orbitais foi avaliada em relação a medidas planialtimétricas precisas adquiridas de 
campanhas de campo com Sistema de Posicionamento Global (GPS). As avaliações foram realizadas seguindo duas abordagens: (1) o uso de Erro Médio Quadrático (EMQ) e (2) testes de hipótese de tendência e precisão. A investigação mostrou que a qualidade planialtimétrica dos produtos orbitais atendeu aos requisitos para a Classe A $(1: 100.000)$ do Padrão de Exatidão Cartográfica brasileiro. Assim, o uso da combinação de informações fornecidas pelos dados PALSAR e SRTM-3 pode ser considerado como uma alternativa promissora para a produção e atualização de mapeamento topográfico de semidetalhe em ambientes similares da região Amazônica, onde a informação topográfica é ausente ou apresenta baixa qualidade.

Palavras-chave: mapeamento topográfico, SRTM-3, ALOS/ PALSAR, orto-imagens, Região Amazônica.

\section{REFERENCES}

ASPRS - AMERICAN SOCIETY FOR PHOTOGRAMMETRY AND Remote SEnsing. 1989. ASPRS Interim Accuracy Stardars for Large-Scale Maps. Photogram Eng Rem Sens, p. 1038-1040.

BRASIL. 1984. Decreto Federal n ${ }^{\circ} 89.817$, de 20 de junho de 1984, Estabelece as Instruções Reguladoras das Normas Técnicas da Cartografia Nacional.

CHENG P. 2007. Automated High-Accuracy Orthorectification and Mosaicking of PALSAR Data without GCP. Geoinformatics 10: 36-38.

FARR TG ET AL. 2007. The Shuttle Radar Topography Mission. Reviews of Geophysics 45: 1-33. doi: 10.1029/2005RG000183.

Frost VS, Stiles JA, Shanmugan KS And Holtzman JC. 1982. A model for radar images and its application to adaptive digital filtering of multiplicative noise, IEEE T Pattern Analysis and Machine Intelligence 2: 157-166.

Galo M AND CAMARgo PO. 1994. O uso do GPS no controle de qualidade de cartas. In: CONGRESSO BRASILEIRO DE CADAstro TÉCNiCO MultifinalitáRIO (COBRAC-1994), 1, Florianópolis, SC. Annals... Florianópolis: UFSC.

Gesch DB, Muller JP AND FARR TG. 2006. The Shuttle Radar Topography Mission - Data Validation and Applications. Photogram Eng Rem Sens 72: 233-235.

Hirano A, Welch R And Lang H. 2003. Mapping from ASTER stereo image data: DEM validation and accuracy assessment. ISPRS J Photogram Eng Rem Sens 57: 356-370.
Hoffmann J AND Walter D. 2006. How Complementary are SRTM-X and -C Band Digital Elevation Models. Photogram Eng Rem Sens 72: 261-268.

IBGE - Instituto BRASILEIRO DE GEOGRAFia E EsTATÍsticA. 2009. MAPGEO - Modelo de Ondulação Geoidal.

Jarvis A, Rubiano J, Nelson A, Farrow A ANd MuliGAN M. 2004. Practical use of SRTM data in the tropics: comparison with digital elevations models generated from cartographic data, Working Document, Vol. 198. Centro Internacional de Agricultura Tropical (CIAT), $32 \mathrm{p}$.

JAXA - JAPAN AEROSPACE EXPLORATION AgEnCY. 2007. Earth Observation Research Center. ALOS User Handbook. NDX-070015.

Lobato LN, Rosiére CA, Silva RCF, ZucChetti M, BaArs FJ, SeoAne JCS, Rios FJ, Pimentel M, Mendes GE And Moteiro AM. 2005. A mineralização hidrotermal de ferro da província mineral de Carajás - controle estrutural e contexto na evolução metalogenética da província. In: ADIMB/DNPM. Caracterização de depósitos minerais em distritos mineiros da Amazônia. Brasília: DNPMCT/MINERAL-ADIMB, cap. 2, p. $21-92,782$ p.

Maune DF (Ed). 2007. Digital Elevation Model Technologies and Applications: the DEM User Manual, $2^{\text {nd }}$ ed., American Society for Photogrammetry and Remote Sensing, ASPRS, Bethesda, Maryland.

Merchant D. 1982. Spatial Accuracy Specification for Large Scale Topographic Maps. Technical Papers of the American Congress on Surveying and Mapping annual meeting, $42^{\text {nd }}$, Denver, CO, p. 222-231.

NGA - National Geospatial-Intelligence Agency. 2009. Information about WGS84, EGM96.

NSDI - National Spatial Data Infraestructure. 1998. Geospatial Positioning Accuracy Standards Part 3: National Standard for Spatial Data Accuracy.

Oliveira CG and Paradella WR. 2008. An Assessment of the Altimetric Information Derived from Spaceborne SAR (RADARSAT-1, SRTM3) and Optical (ASTER) Data for Cartographic Application in the Amazon Region. Sensors 8: 3819-3829.

Oliveira CG AND PARAdella WR. 2009. Evaluating the quality of the Digital Elevation Models produced from ASTER stereoscopy for topographic mapping in the Brazilian Amazon Region. An Acad Bras Cienc 81: 217-225. 
Oliveira CG, Paradella WR And Silva AQ. 2010. Assessment of radargrammetric DSMs from TerraSAR$\mathrm{X}$ Stripmap images in a mountainous relief area of the Amazon region. ISPRS J Photogram Rem Sens 66: 6772. doi: 10.1016/j.isprsjprs.2010.08.008.

OSTROWSKI JA AND CHENG P. 2000. DEM extraction from stereo SAR satellite imagery. In: PROCEEDINGS, IGARSS00. Honolulu Hawaii, USA. IEEE T Geosci and Remote Sens: 2176-2178.

Paradella WR, CeCARelli ICF, Luiz S, Oliveira CG, CotTini CP AND OKIDA R. 2005b. Geração de Carta Topográfica com Estéreo-pares Fine do Radarsat-1 e Dados Etm+ Landsat 7 em Ambiente de Relevo Montanhoso na Região Amazônica (Serra Dos Carajás, Pará). Rev Bras Geocienc 35: 323-332.

Paradella WR, Oliveira CG, Cecarelli iCF, COTTINI CP AND OKIDA R. 2005a. Operational Use of RADARSAT-1 Fine Stereoscopy Integrated with TMLandsat 5 Data for Cartographic Application in the Brazilian Amazon. Can J Remote Sensing 31: 139-148.

Paradella WR, Silva AQ, KnUst SSA, Rabelo TN, SANTOS AR, RENNÓ CD, OLIVEIRA CG AND RODRIGUES TG. 2009. Effect of the Microtopography on RADARSAT- 1 and PALSAR Backscattering from Rock Alteration Products in the Curaçá Valley, Brazil. Can J Remote Sensing 35: 262-269.

PARAdella WR, Silva MFF, Rosa NA AND KushigBOR CA. 1994. A Geobotanical Approach to the Tropical Rain Forest Environment of the Carajás Mineral Province (Amazon Region, Brazil), based on Digital TM-Landsat and DEM Data. Int J Remote Sens 15: 1633-1648.

Paradella WR, Veneziani P, Bignelli PA, Pietsch RW AND TOUTIN T. 1997. Airborne and spaceborne synthetic aperture radar (SAR) integration with Landsat TM and gamma ray spectrometry for geological mapping in a tropical rainforest environment, the Carajás Mineral Province, Brazil. Int J Remote Sens 18: 1483-1501.

PCI Geomatics. 2010. Geomatica OrthoEngine User Guide, version 10.3, Ontario, Richmond Hill, Canada, $168 \mathrm{p}$.

Rodriguez E, Morris CS, Belz JE, Chapin EC, MarTIN JM, DAFFER W AND Hensley S. 2005. An assessment of the SRTM topographic products, Technical Report JPL D-31639, Jet Propulsion Laboratory, Pasadena, California, $143 \mathrm{p}$.

Santos AR, Paradella WR and Veneziani P. 2003. Avaliação da esteroscopia SAR (RADARSAT-1) e híbrida
(RADARSAT-1 \& TM-Landsat-5) em mapeamento geológico na Província Mineral de Carajás. Rev Bras Geocienc, São Paulo 33: 153-160.

SAntos JR, NARVAes IS, GRAÇA PMLA AND GONÇALVES FG. 2009. Polarimetric responses and scattering mechanisms of tropical forests in the Brazilian Amazon. In: Geoscience And Remote Sensing. ed., Aleksandar Lazinica. IN-TECH, Vienna, Austria, Chapter 8, p. 183-206.

SBC - Sociedade Brasileira de CARTografia. 2006. Sociedade Brasileira de Cartografia. Contribuição do Exército a questão Amazônica - A questão do vazio Cartográfico. Boletim - Trimestral Janeiro/Fevereiro/Março n. 62 .

SHAKER A. 2008. Satellite sensor modeling and 3D geopositioning using empirical models. Int J Applied Earth Obs and Geoinf 10: 282-295.

SHIMAdA M, Isoguchi O, TADONO T, Higuchi R AND IsONO K. 2007. PALSAR CALVAL Summary and Update 2007. In: ProceEdings, IGARSS07. Barcelona, Spain: IEEE T Geosci and Remote Sens, p. 3593-3596.

Silva ADQ, Paradella WR, Freitas CC And OliveiRA CG. 2009. Relationship between PALSAR backscatter and surface-roughness parameters from iron laterites in Carajás, Amazon Region. IEEE T Geosci and Remote Sens 47: 4027-4031.

Silva MG, Teixeira JBG, Pimentel MM, VAsconceLos PM, ARIElo A AND Rocha WJSF. 2005. Geologia e mineralizações de $\mathrm{Fe}-\mathrm{Cu}$-Au do Alvo GT46 (Igarapé Cinzento), Carajás A mineralização hidrotermal de ferro da província mineral de Carajás - controle estrutural e contexto na evolução metalogenética da província. In: ADIMB/DNPM. Caracterização de depósitos minerais em distritos mineiros da Amazônia. Brasília: DNPMCT/ MINERAL-ADIMB, cap. 2, p. 93-151, 782 p.

Teruiya RK, Paradella WR, Santos AR, Dall'AgNOL R AND VENEZIANI P. 2008. Integrating airborne SAR, Landsat TM and airborne geophysics data for improving geological mapping in the Amazon region: the Cigano Granite, Carajás Province, Brazil. Int J Remote Sens 29: 3957-3974.

Toutin T. 1998. Stereo RADARSAT for mapping applications. In: ProceEdings, ADRO Final Symposium, Montreal, Canadá, CD-ROM.

Toutin T. 1999. Error tracking of radargrammetric DEM from RADARSAT images. IEEE T Geosci and Remote Sens 37: 2227-2238. 
Toutin T. 2004. Review article: Geometric processing of remote sensing images: models, algorithms and methods. Int J Remote Sens 25: 1893-1924.

TOUTIN T AND CARBOnNEAU Y. 1992. La création d'ortho-images avec mne: description d'un nouveau système. Can J Remote Sens 18: 136-141.

Toutin T, CArbonneau Y And St-Laurent L. 1992. An integrated method to rectify airborne radar imagery using DEM. Photogram Eng Rem Sens 58: 417-422.
USGS - DEPARTMENT OF THE INTERIOR, U.S. GEOLOGICAL SurVeY. NATIONAL MAPPING Division. 1998. Standards or digital elevation models. Reston, VA.

Veneziani P, SANTos AR AND PARAdella WR. 2004. A evolução tectono-estratigráfica da Província Mineral de Carajás: um modelo com base em dados de sensores remotos orbitais (SAR-C RADARSAT-1, TM-Landsat-5), aerogeofísica e dados de campo. Rev Bras Geocienc, São Paulo 34: 67-78. 